\title{
BOTTOM TOPOGRAPHY AND INTERNAL LAYERS IN EAST DRONNING MAUD LAND, EAST ANTARCTICA, FROM 179 MHz RADIO ECHO-SOUNDING
}

\author{
by \\ Minoru Yoshida* \\ (National Institute of Polar Research, Tokyo 173, Japan) \\ with \\ Kazunobu Yamashita
}

(Fifth Region Maritime Safety Headquarters, Maritime Safety Agency, Kobe 650, Japan)

and

Shinji Mae

(Department of Applied Physics, Faculty of Engineering, Hokkaido University, Sapporo 060, Japan)

\begin{abstract}
Extensive echo-sounding was carried out in east Dronning Maud Land during the 1984 field season. A 179 $\mathrm{MHz}$ radar with separate transmitting and receiving antennae was used and the echoes were recorded by a digital system to detect minute reflections. The results gave cross-sections of the ice sheet along traverse routes from lat. $69^{\circ} \mathrm{S}$. to $75^{\circ} \mathrm{S}$. Detailed observations on the ground at Mizuho station showed that there was elliptical polarization in the internally reflected echoes when two antennae, kept in parallel with each other, were rotated horizontally. The internal echoes were most clearly distinguished when the antenna azimuth was oriented perpendicular to the flow line of the ice sheet. The internal echoes with a high reflection coefficient were detected at depths of $500-700 \mathrm{~m}$ and $1000-1500 \mathrm{~m}$ at Mizuho station. Since a distinct internal echo at a depth of $500 \mathrm{~m}$ coincides with a $5 \mathrm{~cm}$ thick volcanic ash-laden ice layer found in the $700 \mathrm{~m}$ ice core taken near the observation site, these echoes may correspond to the acidic ice layers formed by past volcanic events in east Dronning Maud Land.
\end{abstract}

\section{INTRODUCTION}

The Japanese Antarctic Research Expedition (JARE) has carried out extensive glaciological work in the inland area of east Dronning Maud Land since 1982. During the last two seasons, radio echo-sounding was conducted at the lower altitudes (Nakawo and others 1984; Nishio and others 1986). They used $60 \mathrm{MHz}$ radar for the ground survey and $179 \mathrm{MHz}$ radar for the airborne survey.

The authors carried out the ground survey by $179 \mathrm{MHz}$ radar at the higher altitudes during the 1984 field season. A-scope data were recorded every $10-20 \mathrm{~km}$ along the new traverse route (Fig.1). The object of the observations was to measure the ice thickness along the route and the positions of the internal echoes.

\section{RADAR SYSTEM}

The radar transmits a $1.5 \mathrm{kw}$ (peak) pulse in a repetition frequency of $1 \mathrm{kHz}$. The receiver has a sensitivity

* Present address: Hakusan Industry Co. Ltd, Tokyo 183, Japan.

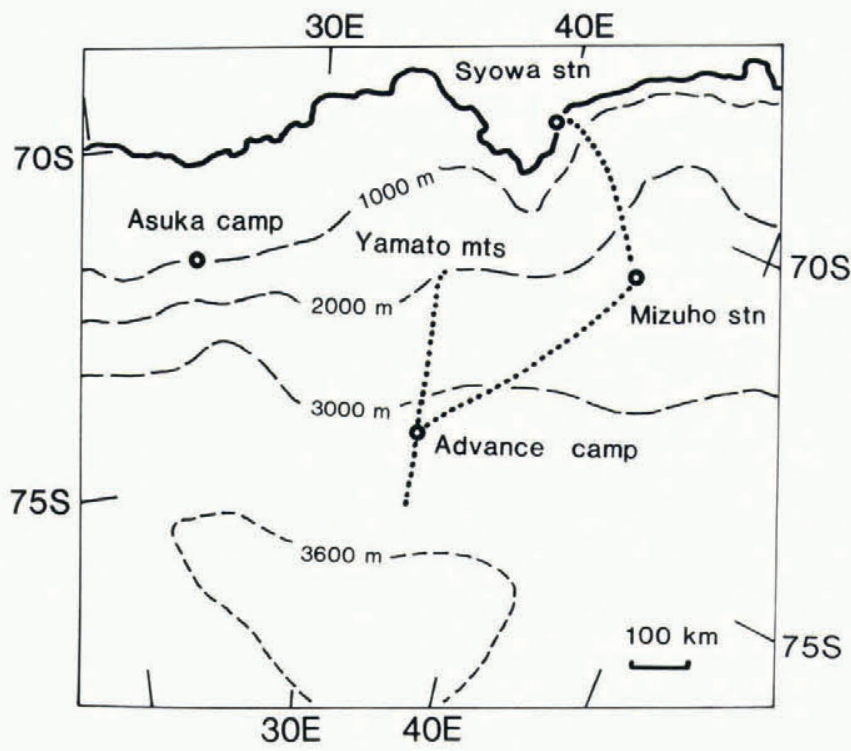

Fig.1. Inland traverse route during 4 October-5 December 1984.

of $-104 \mathrm{dBm}$, whose receiving frequency is $179 \mathrm{MHz} \pm 2.5$ $\mathrm{kHz}$. Six-element Yagi antennae were used as the transmitting and receiving aerials which had linear polarizations. These antennae were set up on the snow, maintaining parallelism to each other at a distance of $3 \mathrm{~m}$ during the observations.

Wada and others (1982) reported that this radar with a three-element Yagi antenna failed to detect echoes from the bed deeper than $1500 \mathrm{~m}$ when the radar was used for airborne surveys. In order to detect minor echoes, we have analyzed the A-scope data by a digital recording system. After having been digitized at $50 \mathrm{~ns}$ intervals, 256-512 received echoes were stacked in a memory to eliminate random noises. The A-scope echo shown on the CRT was also recorded as a photograph which was exposed for 20-30 s. This photographic film also represents the optically averaged echo from $20000-30000$ received signals. 


\section{RESULTS AND DISCUSSION}

The radar system successfully detected all of the echoes from the bed along the route. Fig. 2 shows a cross-section of the ice sheet along the traverse route obtained both by the echo-sounding and the surveyed altitudes of the ice

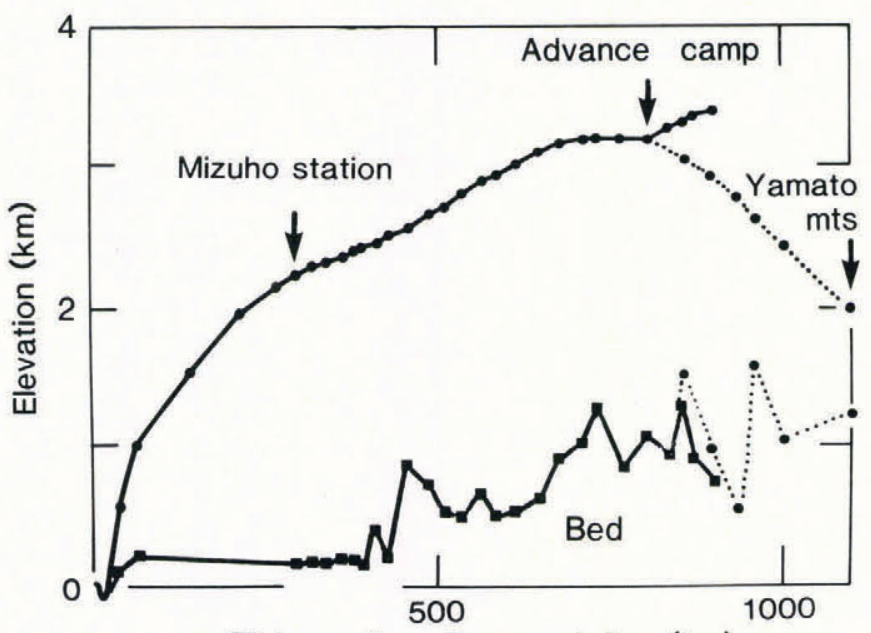

Distance from Syowa station $(\mathrm{km})$

Fig.2. Cross-section of the ice sheet along the traverse route. Surface elevations of the ice sheet are based on the data of Fujii and others (1986).

surface. The ice thickness was determined by the echo time from the bed, assuming that the radio-wave velocity in the ice is $169 \mathrm{~m} / \mu \mathrm{s}$. The bed elevations in latitudes lower than $72^{\circ} \mathrm{S}$. are $100-200 \mathrm{~m}$ a.s.1. In the higher-latitude area, the bed elevations increase to $500-1000 \mathrm{~m}$ and the bottom topography is extremely rough. The thickest ice along the route was $2650 \mathrm{~m}$ at lat. $75^{\circ} \mathrm{S}$. The traverse party of JARE-26 extended this route to lat. $78^{\circ} \mathrm{S}$. in 1985 and reported $3500-4000 \mathrm{~m}$ thick ice there (personal communication from K. Kamiyama).

The observations on the internal echoes were carried out at Mizuho station (lat. $70^{\circ} 42^{\prime}$ S., long. $44^{\circ} 20^{\prime} \mathrm{E}$., $2230 \mathrm{~m}$ a.s.1.). Although polarization in the ice sheet, observed when the transmitting antenna was rotated around the fixed receiving antenna $\mathbf{R}$, has been reported in a number of papers (e.g. Hargreaves 1978, Woodruff and Doake 1979), few observations on polarization when two aerials are kept parallel to one another have been reported (e.g. Bentley 1975). Furthermore, these reports are based on analyses of the bottom-reflected signals; it seems that there have been virtually no reports on polarization resulting from internal echoes. Since the bottom-reflected echoes are affected not

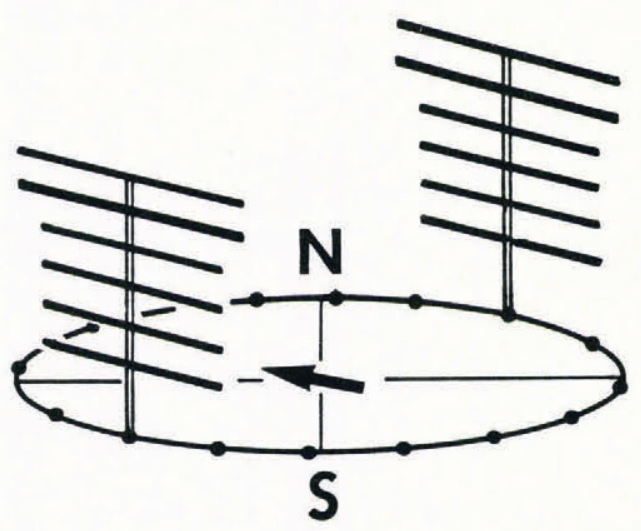

Fig.3. Setting of the antennae. The ice-flow direction is shown at the center. This direction is equal to that of the principal axis of the extending strain of the ice sheet (Naruse and Shimizu 1978). only by the birefringence of the ice but also by the morphology of the glacier bed (Berry 1975), it is necessary to analyze the internal echoes in order to determine the birefringence of the ice body itself. We observed the A-scope data for the internal echoes, when the receiving antenna was rotated around the transmitting antenna, and kept parallel to one another at a distance of $3 \mathrm{~m}$. Measurements were repeated at $22.5^{\circ}$ intervals (Fig.3). In order to evaluate the relationship between the polarization and the strain of the ice sheet, the antennae were installed on the snow at the center of a strain-grid which had been set up for observation of the strain-rate of the ice sheet.

Fig.4 shows the noise-reduced A-scope data at the same travel-time (depth) scale which clearly indicates

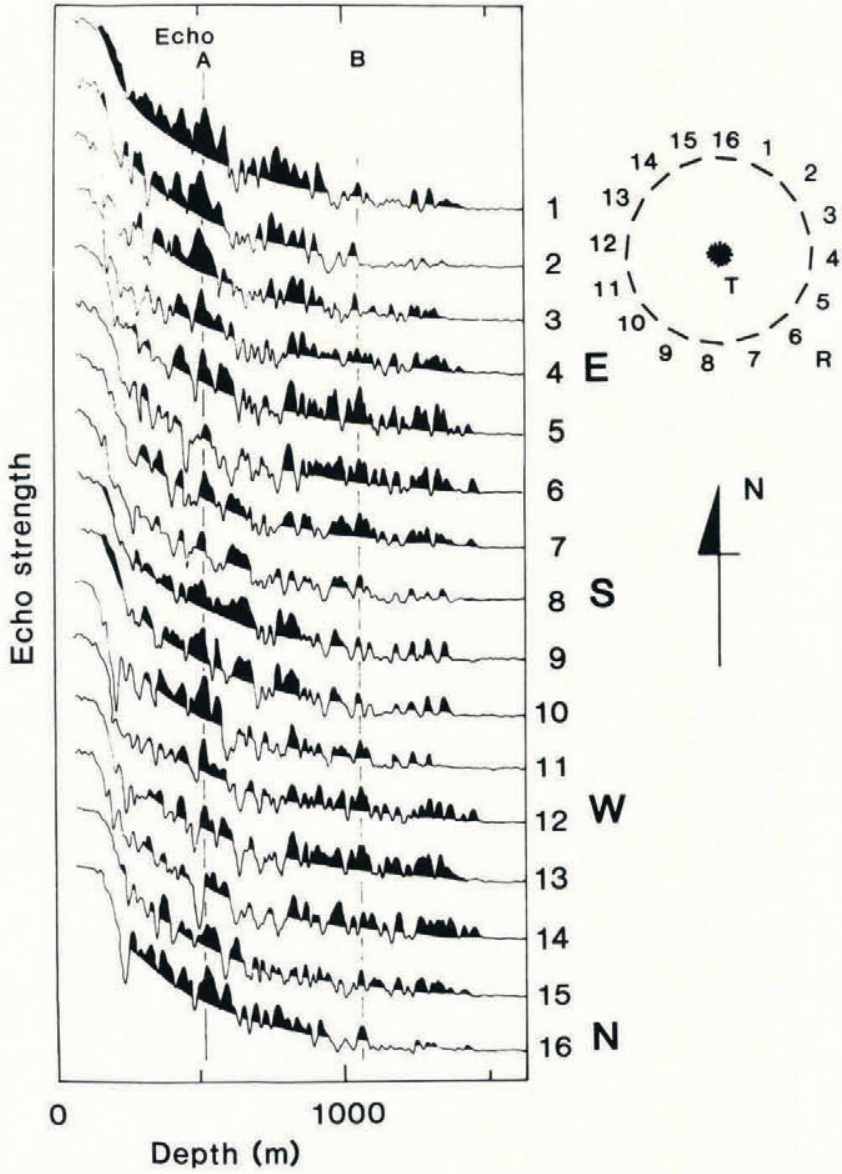

Fig.4. Internal echoes at 16 different antenna azimuths observed by A-scope data. Echo strengths above the average level of the 16 data sets obtained by A-scope are coloured dark. $R$ and $T$ represent the two parallel antennae, receiving and transmitting aerials, respectively. The observation was carried out in May 1984.

polarization of a radio wave in the ice sheet. The internal echoes from a depth of $1000-1500 \mathrm{~m}$ are strongest when the receiving antenna $R$ is situated at east-south-east from the transmitting antenna $\mathrm{T}$ (No. 4, 5, 6 in the illustration) or west-north-west (No. 12, 13, 14).

In order to analyze the echo strength with respect to the antenna azimuth, two internal echoes at depths of $500 \mathrm{~m}$ (echo A) and $1050 \mathrm{~m}$ (echo B) were chosen. Fig.5 shows the results. Both echoes $A$ and $B$ show an elliptical pattern, which confirms the birefringence of the ice sheet. The difference between the maximum and minimum echo strengths is a gain of $7-10 \mathrm{~dB}$, which is a significant value for the receiver sensitivity.

The A-scope records in Figs. 4 and 5 indicate that the internal layers could be most clearly distinguished when the azimuth was perpendicular to the flow line. The internal echo from a depth of $1050 \mathrm{~m}$ (echo B) became strongest 


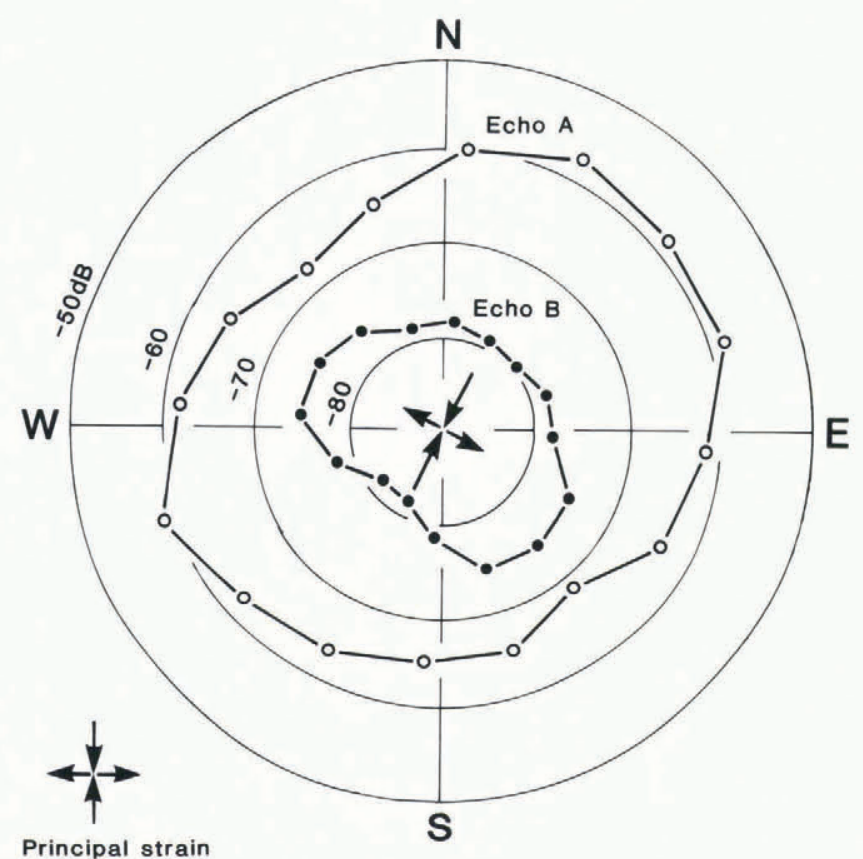

Fig.5. Echo strength as a function of the direction of the two parallel antennae. The positions of echo $\mathrm{A}$ and echo B are shown in Fig.3. The directions of the principal strain axes of the ice sheet observed at the same time are shown at the center of the circle graph.

when the antenna azimuth faced $030^{\circ}$ or $210^{\circ}$ ( $R$ was situated at $120^{\circ}$ or $300^{\circ}$ (from T). This antenna azimuth is very close to that of the principal compressive strain of the ice sheet, which is perpendicular to the flow line at the observation site. This coincidence of the azimuth may suggest that the birefringence was caused by the ice flow. Narita and others (in press) have examined the $700 \mathrm{~m}$ deep ice core from Mizuho station and have reported that the c-axes of the ice crystals below $400 \mathrm{~m}$ depth become aligned along the vertical plane. It is plausible that the strain history of the ice has caused this orientation fabric, which may determine the birefringence of a polycrystalline ice sheet as Hargreaves (1978) has argued in a theoretical study.

Another possible cause of this polarization could be explained by the depositional pattern of the internal layers. Internal layers, such as volcanic ash layers, probably have prolonged patch-patterns due to the strain deformation of the ice sheet. The reflection coefficients of these irregular patches would depend on the azimuths of the antennae.

Millar (1981) has analyzed the internal echoes in the Greenland ice sheet and he concluded that the internal echo layering was formed by layers of ice of changed composition, which are probably composed of acidic ice formed after volcanic eruptions. Since we have found a $5 \mathrm{~cm}$ thick volcanic ash-laden ice layer at Mizuho station (Narita and others in press), the A-scope record when the antenna azimuth was perpendicular to the flow line has been compared with the position of the ash-laden ice layer. The result (Fig.6) represents a strong echo up to $20 \mathrm{~dB}$ peak at the depth of the volcanic ash-laden ice layer. This coincidence suggests that the echo strength/depth profile corresponds to acidic layers caused by past volcanic activity in east Dronning Maud Land.

Although dating of the ash-laden ice layer at $500 \mathrm{~m}$ depth has not yet been completed, from the annual accumulation rate of $7 \mathrm{~g} /$ year at Mizuho station (Watanabe and others 1978) the age can be estimated as $\sim 8 \times 10^{3}$ year B.P. Other internal layers with high reflection coefficients seem to be located at $1000-1500 \mathrm{~m}$ depth. The ages of these ice layers can be estimated as between 20 and $40 \times 10^{3}$ year B.P. These ages of the internal layers seem to coincide with those of volcanic ash bands found in the ice core at Byrd Station (Gow and Williamson 1971); this coincidence

\section{Dirt Echo strength (dB)}

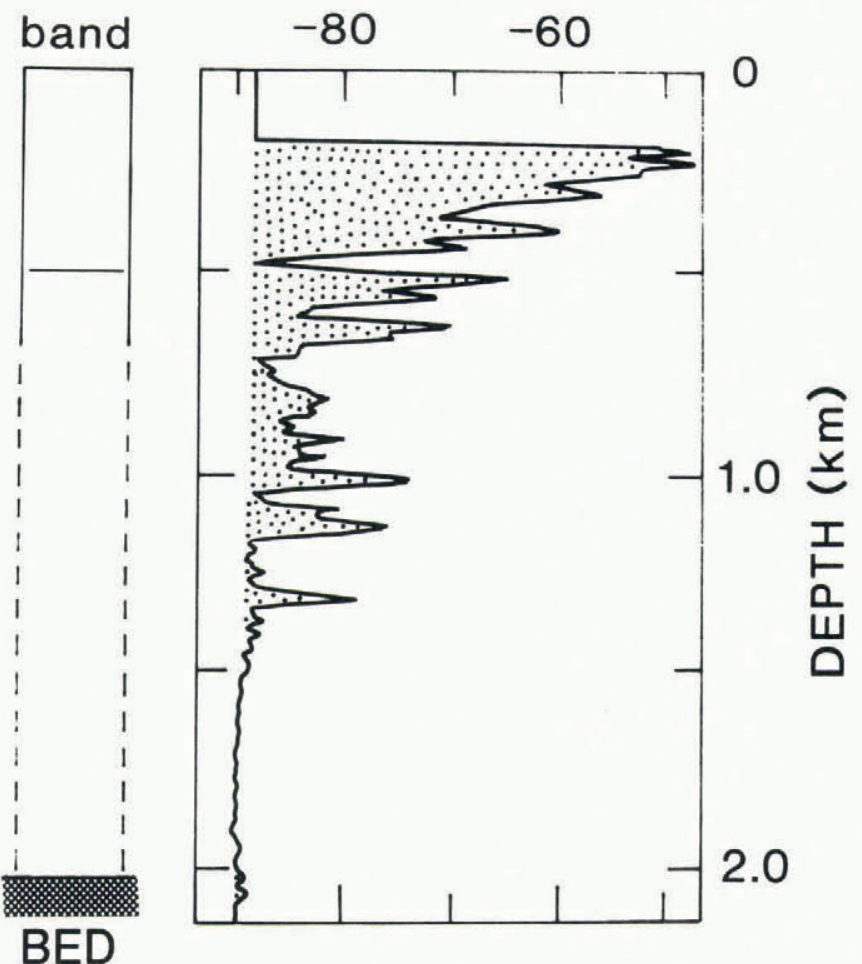

Fig.6. Internal echo and the depth of the volcanic ash layer at Mizuho station. The antennae azimuths were perpendicular to the direction of ice flow. Echo sounding was carried out in December 1984.

may suggest the extensive fall-out of acidic aerosols on the Antarctic ice sheet. Further echo-sounding of internal layers will undoubtedly reveal the areal distribution of these volcanic ash layers during the last glaciation.

\section{ACKNOWLEDGEMENT}

The radio echo-sounding data were collected during the JARE-25 programme in 1983-85. The authors would like to thank the members of the wintering party, led by Professor T Hirasawa, for their enthusiastic field support. We also wish to express our thanks to Dr F Nishio, Dr H Ohmae, Dr K C Jezek and Dr R S Williams for their helpful advice.

\section{REFERENCES}

Bentley C R 1975 Advances in geophysical exploration of ice sheets and glaciers. Journal of Glaciology 15(73): 113-135

Berry M V 1975 Theory of radio echoes from glacier beds. Journal of Glaciology 15(73): 65-74

Fujii Y, Kawada K, Yoshida M, Matsumoto S 1986 Glaciological research program in east Queen Maud Land, East Antarctica. Part 4, 1984. JARE Data Reports 116 (Glaciology 13)

Gow A J, Williamson T 1971 Volcanic ash in the Antarctic ice sheet and its possible climatic implications. Earth and Planetary Science Letters 13(1): 210-218

Hargreaves N D 1978 The radio-frequency birefringence of polar ice. Journal of Glaciology 21(85): 301-313

Millar D H M 1981 Radio-echo layering in polar ice sheets and past volcanic activity. Nature 292(5822): 441-443

Nakawo M, Narita H, Isobe T 1984 Glaciological research program in east Queen Maud Land, East Antarctica. Part 2, 1983. JARE Data Reports 96 (Glaciology 11)

Narita $H$, Fujii $Y$, Nakawo $M$ In press Morphological observations of structure and fabric patterns of $700 \mathrm{~m}$ deep ice core obtained at Mizuho Station, Antarctica. Memoirs of National Institute of Polar Research. Special Issue 
Naruse R, Shimizu H 1978 Flow line of the ice sheet over Mizuho Plateau. Memoirs of National Institute of Polar Research. Special Issue 7: 227-234

Nishio F, Ohmae H, Ishikawa M 1986 Glaciological research program in east Queen Maud Land, East Antarctica. Part 3, 1982. JARE Data Reports 110 (Glaciology 12)

Wada M, Yamanouchi T, Mae S 1982 Radio echo-sounding of Shirase Glacier and the Yamato Mountains area. Annals of Glaciology 3: 312-315

Watanabe O, Kato K, Satow K, Okuhira F 1978 Stratigraphic analyses of firn and ice at Mizuho Station. Memoirs of National Institute of Polar Research. Special Issue 10: $25-47$

Woodruff A H W, Doake C S M 1979 Depolarization of radio waves can distinguish between floating and grounded ice sheets. Journal of Glaciology 23(89): 223-232 